\section{PENGARUH STRATEGI PEMASARAN WORD OF MOUTH (WOM) DAN PRODUK PEMBIAYAAN SYARIAH TERHADAP MINAT DAN \\ KEPUTUSAN MENJADI ANGGOTA (NASABAH) PADA BAITUL TAMWIL MUHAMMADIYAH (BTM) KOTA BANDAR LAMPUNG}

Syifa Zakia Nurlatifah ${ }^{1}$, R.Masykur ${ }^{2}$

${ }^{1}$ Sekolah Tinggi Ekonomi Islam Tazkia (STEI Tazkia), ${ }^{2}$ Fakutltas Tarbiyah dan Keguaruan UIN Raden Intan Lampung

1'syifazakia@yahoo.co.id, ${ }^{2}$ rmasykur@yahoo.co.id
JURNAL

MANAJEMEN

INDONESIA

Vol.17 No.3

Desember 2017

\begin{abstract}
Abstrak
Promosi Word Of Mouth dalam dunia perbankan semakin penting dan memiliki strategi yang lebih efektif dibandingakan dengan strategi promosi yang lainnya. Penelitian ini bertujuan untuk mengetahui dan menganalisis pengaruh strategi pemasaran dengan Word of Mouth terhadap minat menjadi anggota (nasabah), menganalisis pengaruh produk pembiayaan syariah terhadap minat dan bagaimana pengaruh strategi pemasaran Word of Mouth terhadap keputusan. Selain itu, penelitian ini juga ingin mengetahui pengaruh produk pembiayaan syariah terhadap keputusan, serta pengaruh minat terhadap keputusan. Proses analisis dilakukan dengan pengumpulan data dengan metode observasi, wawancara dan kuisioner. Data yang telah terkumpul diolah dengan menggunakan alat analisis deskriptif kualitatif dan kuantitatif. Teknik analisa yang dipergunakan untuk menganalisis data adalah analisis SEM (Structural Equation Model). Analisis SEM pada penelitian ini menggunakan PLS dengan bantuan software Smart PLS. Hasil penelitian dilihat bahwa original sample Word of Mouth berpengaruh positif dan pengaruh yang signifikan (berarti) terhadap minat, sample Word of Mouth memiliki pengaruh yang positif terhadap keputusan dengan pengaruh yang signifikan (berarti), untuk sampel produk berpengaruh positif terhadap minat dan berpengaruh yang positif terhadap keputusan, dan sampel terakhir minat terhadap keputusan terbukti tidak berpengaruh signifikan antara terhadap keputusan.
\end{abstract}

Kata Kunci: WOM, Produk, Minat, Keputusan, SEM

\section{Abstract}

Word Of Mouth promotion in the banking world is increasingly important and has a more effective strategy compared to other promotional strategies. This study aims to know and analyze the influence of marketing strategy with Word of Mouth on the interest of being a member (customer), to know and analyze the influence sharia financing products to interest and how influence of Word of Mouth marketing strategy to the decision. Moreover, this study also wants to know the effect of shariah financing products against the decision, and the influence of interest in the decision. The process of analysis with data collection conducted by the method of observation, interview and questionnaire. The data have been collected processed by using descriptive analysis tools qualitative and quantitative. The analysis technique used to analyze the data is SEM (Structural Equation Model) analysis. SEM analysis in this research using PLS with the help of Smart PLS software. The result of research show that original sample Word of Mouth have positive influence and significant influence on interest, Word of Mouth samples have positive influence on decision with significant influence (meaning), for product samples have positive effect on interest and have positive influence against the decision, and the final sample of interest on the decision proved to have no significant effect between the decision.

Keywords: WOM, Product, Interests, Decision, SEM 


\section{Pendahuluan}

Ajaran Islam adalah pedoman bagi umat manusia dan berfungsi sebagai Rahmatan Lil'alamin. Ajaran ini bersifat komprehensif dan sempurna dalam mengatur seluruh sendi kehidupan manusia dan alam semesta. Islam adalah suatu sistem dan jalan hidup yang utuh dan terpadu (a comprehensive way of life). Pedoman yang diajarkan Islam sebagai panduan yang dinamis dan lugas terhadap semua aspek dan lini kehidupan, termasuk sektor bisnis dan transaksi keuangan.

Seiring dan sejalan dengan perubahan perkembangan tentang perekonomian, maka munculah berbagai lembaga keuangan yang beroreintasi kepada ajaran syariah. Lembaga keuangan syariah ini mengalami kemajuan yang sangat pesat, bank konvensional yang juga ikut menjadi bank syariah, tidak saja bank yang menjadi pendukung perekonomian syariah. Disamping itu, banyak juga berdiri lembaga keuangan syariah seperti asuransi syariah, dan Baitul Maal wat-Tamwil (BMT) yang selalu disediakan tawaran aqad yang beroreintasi kepada syariah, sehingga para nasabah diberikan kesempatan untuk memilih salah satu aqad yang sesuai dengan syariah.

Lembaga-lembaga keuangan syari'ah dengan system profit and loos sharing yang mulai semakin berkembang hal ini diperkuat dengan undang-undang No.7 tahun 1992 sebagai legalitas payung hukum terhadap berdirinya bank syariah di Indonesia dan undang-undang tersebut telah disempurnakan dengan UU tahun 1998. Lembaga keuangan syariah hadir sebagai jawaban terhadap kekhawatiran masyarakat akan keharaman hutang piutang berbasis bunga atau ribawi.

Salah satu jenis lembaga keuangan syariah adalah Baitul Maal wat-Tamwil (BMT). Jenis lembaga ini dalam menjalankan aktivitasnya berorientasi kepada prinsip syariah. Baitul Maal wat-Tamwil berdiri dengan gagasan akan fleksibilitas dalam menjangkau masyarakat pada kalangan bawah yaitu lembaga ekonomi rakyat kecil.

Selain Baitul Maal wat-Tamwil salah satu lembaga yang menjalankan produk keuangan syariah khususnya di Bandar Lampung adalah Baitul Tamwil Muhammadiyah (BTM). Lembaga ini merupakan salah satu lembaga keuangan syariah yang menyediakan produk dalam bentuk aqad yang bisa menjadi pilihan para anggota atau calon anggota untuk melakukan kegiatan ekonomi secara syariah dengan menggunakan beberapa produk yang disediakan. Sehingga, perlu dianalisis dan diketahui bagaimana pengaruh strategi pemasaran dengan menggunakan Word of mouth dari produk pembiayaan lembaga syariah terhadap minat dan pengambilan keputusan menjadi anggota (nasabah) pada Baitul Tamwil Muhammadiyah (BTM) Kota Bandar Lampung.

\section{Landasan Teori dan Metodologi}

\subsection{Strategi Marketing Word of Mouth}

Kelebihan Word of Mouth cukup banyak seperti telah dikatakan dalam hasil penelitian Kartz dan Lazarfeld dalam Walker (2001:60) dan juga dikutip oleh Sutisna (2003:184) mengatakan bahwa komunikasi Word of Mouth itu ternyata tujuh kali lebih efektif dari pada iklan melaui media surat kabar dan majalah, empat kali lebih efektif daripada dengan penjualan pribadi, dan dua kali lebih efektif daripada iklan di radio. Beberapa pendapat para ahli tentang Word of Mouth (WOM) disebutkan sebagai berikut:

1) Rowley (2006:128), membagi saluran komunikasi melalui personal dan nonpersonal. Prosesnya bisa terjadi dengan dua orang atau lebih berkomunikasi dengan yang lainnya. Komunikasi Word of Mouth akan terjadi dengan tatap muka secara individu atau kelompok, online melalui diskusi kelompok, percakapan antarruang (chat rooms), maupun buletin.

2) Mathews (2009:119) juga membagi Word of Mouth dalam 2 (dua) level, yaitu expert dan peer. Penulis berpendapat bahwa BTM juga harus memiliki tenaga yang mempunyai expert (ahli) dalam kepakaran ketika berkomunikasi menyampaikan pesan dalam bentuk program.

\section{Jurnal Manajemen Indonesia}


3) E. Anderson 1998; Arndt 1968; Buttle 1998 dalam Walker (2001:63), dijelaskan definisi dari word of mouth, yaitu: "word of mouth may be defined as informal, person to person communication between a perceived noncommercial communicator and a receiver regarding a brand, a product, an organization, or a service".

4) Sumardy dan Melone (2011), Word of Mouth diartikan sebagai tindakan penyediaan informasi oleh konsumen kepada konsumen lain. Selanjutnya dalam Lovelock, et.al. (2005) disebutkan kalau Word of Mouth merupakan rekomendasi yang berasal dari konsumen lain yang dipandang secara umum dapat dipercaya dibandingkan dengan aktifitas perusahaan berupa promosi, dimana kegiatan ini dapat mempengaruhi keputusan orang untuk menggunakan atau tidak menggunakan suatu produk.

5) Dowd (2010:9), elemen dasar dalam Word of Mouth terdiri dari: mengidentifikasi yang mempengaruhi, membuat gagasan menjadi sederhana sehingga mudah dikomunikasikan, memberi orang alat bagaimana mereka perlu menyampaikan dengan kata-kata, menggunakan percakapan, maupun dengan cara mengevaluasi dan mengukur.

6) Menurut American Word of Mouth Marketing Association, sebagaimana dikutip oleh Smith (2010:40) dan kelly $(2007 ; 149)$, yaitu: “....... is giving people a reason to talk about your products and services and making it easier for that conversation to take place."

Komunikasi Word of Mouth memiliki konsep bahwa komunikasi dengan Word of Mouth lebih diandalkan dan jelas memainkan peran yang sangat penting dalam mempengaruhi minat dan keputusan anggota Baitul Tamwil Muhammadiyah Kota Bandar Lampung. Jadi sisi positif dari pelaksanaan Word of Mouth mengarah pada adanya minat anggota untuk mengambil keputusan menjadi anggota Baitul Tamwil Muhammadiyah kota Bandar Lampung.

Beberapa penelitian mengenai word of mouth telah banyak dilakukan dan dipublikasikan melaui jurnal-jurnal. Salah satu hasil penelitian yang dilakukan oleh Maru File dkk (1994) mengatakan bahwa masukan sebagai (input) dan produk sebagai (output) word of mouth dapat mempengaruhi terhadap minat atau keinginan seseorang untuk melakukan pembelian secara berulang mengenai sesuatu prodak yang diinginkan. Dengan demikian penelitian ini membuktikan bahwa Word of Mouth memberikan sumbangan yang positif terhadap keinginan seseorang untuk melakukan pembelian secara berulang selagi produk itu sesuai dengan minatnya. Menurut Ng dkk. (2011), dalam penelitiannya mengenai manfaat hubungan pada kualitas suatu hubungan dan aspek dari kualitas suatu pelayanan, yaitu mengenai suatu perilaku terhadap kualitas teknis dan kualitas fungsional serta pengaruh terhadap Word of Mouth. Beberapa variabel yang digunakan dalam penelitiannya yaitu confident benefits, special treatment benefits, social benefits, fungsional quality, technical quality dan relationship quality. Sehingga menyatakan bahwa hubungan antara confidence benefits memiliki pengaruh terbesar terhadap Word of Mouth, sedangkan social benefits terbesar kedua yang berpengaruh positif terhadap Word of Mouth, sebaliknya bagi special treatment benefits tidak berpengaruh positif terhadap Word of Mouth. Artinya baik fungsional quality dan relationship quality menunjukkan dampaknya terhadap aspek penyediaan layanan dan mempengaruhi niat pelanggan untuk mendorong, merekomendasikan atau mengatakan positif tentang penyedia layanan yang memainkan peran penting dalam menghasilkan suatu perilaku word of mouth.

Pendapat lain mengatakan bahwa definisi Word of Mouth dalam Mix (2007) adalah usaha marketing yang memicu konsumen untuk membicarakan, mempromosikan, merekomendasikan, dan menjual produk/merk kita kepada pelanggan lain. Menurut Kotler (1997), definisi word of mouth Communication adalah komunikasi pribadi tentang suatu produk antara pembeli sasaran dan para tetangga, teman, anggota keluarga, serta rekannya. Menurut Prasetijo dan Ihalauw (2004:47), Word of Mouth Communication adalah komunikasi informal tentang produk atau jasa berbeda dengan komunikasi formal karena dalam komunikasi informal pengirim tidak berbicara dalam kapasitas seorang profesional atau komunikator komersial, tetapi cenderung sebagai teman. Komunikasi ini juga disebut komunikasi dari mulut ke mulut atau gethok tular (Word of Mouth Communication) yang cenderung lebih persuasif karena pengirim pesan tidak mempunyai kepentingan sama sekali atas tindakan penerima setelah itu. Komunikasi ini sangat bermanfaat bagi pemasar. 
Word of Mouth (WOM) artinya komunikasi dari mulut ke mulut, maksudnya proses komunikasi yang berupa pemberian rekomendasi baik secara individu maupun kelompok terhadap suatu produk atau jasa yang bertujuan untuk memberikan informasi. Komunikasi dari mulut ke mulut merupakan salah satu saluran komunikasi yang sering digunakan oleh perusahaan yang menghasilkan suatu produk baik barang maupun jasa, sehingga strategi ini dinilai sangat efektif dalam memperlancar proses marketing dan mampu memberikan keuntungan bagi perusahaan (Kotler, 1997). Jadi strategi ini digunakan oleh perusahaan untuk menyampaikan produk melalui komunikasi baik antar pribadi maupun kelompok tentang barang atau jasa yang ditawarkan kepada konsumen atau nasabah. Strategi ini dianggap penting bagi sebuah lembaga yang melahirkan produk, sekaligus menjadi sumber informasi yang kuat dalam mempengaruhi para calon nasabah atau anggota tetap untuk mengambil keputusan membeli produk tersebut. Ada beberapa alasan pentingnya Word of Mouth bagi suatu lembaga yang menawarkan jasa atau barang, yaitu: (1) Word of Mouth adalah sebagai sumber informasi yang independent dan jujur, (2) Word of Mouth sangat kuat memberikan manfaat kepada yang bertanya dengan pengalaman langsung tentang produk melalui pengalaman teman, (3) Word of Mouth disesuaikan dengan orang-orang tertarik didalamnya, (4) menghasilkan informasi media informal, (5) Word of Mouth dapat dimulai dari satu sumber tergantung bagaimana kekuatan influencer dan jaringan sosial itu menyebar dengan cepat dan secara luas kepada orang lain, (6) Word of Mouth tidak dibatasi oleh ruang atau kendala lainnya, seperti ikatan sosial, waktu, keluarga atau hambatan fisik lainnya (Hasan, 2010).

Dilihat dari aspek kemanfaatan Word of Mouth seperti telah dikemukakan oleh Kotler (1997) berpendapat bahwa ada dua manfaat yang diperoleh dari komunikasi dari Word of Mouth (mulut ke mulut), yaitu: (a) Komunikasi dari mulut ke mulut bersifat lebih meyakinkan. Katakata yang keluar dari mulut merupakan satu-satunya promosi yang berasal dari konsumen oleh konsumen dan untuk konsumen; (b) Komunikasi dari mulut ke mulut tidak memerlukan biaya yang mahal. Selain manfaat juga Word of Mouth merupakan strategi marketing yang dapat digunakan dalam memasarkan produk. Selain itu ada juga beberapa cara yang dapat digunakan untuk melakukan strategi marketing Word of Mouth adalah sebagai berikut (Irawan, 2007:37)

1) Pasarkan produk kepada orang yang paling berpengaruh dalam satu komunitas, mengetahui tentang perkembangan produk terbaru, serta senang berbagi cerita kepada rekan atau kerabatnya mengenai hal - hal yang mereka ketahui. Sehingga semakin banyak orang yang mengetahui informasi mengenai bisnis dan menyebarluaskan informasi tersebut kepada konsumen lain.

2) Memberikan pelayanan yang terbaik bagi setiap konsumen. Konsumen yang memperoleh kepuasan dari sebuah produk atau jasa, secara tidak langsung akan menginformasikan kelebihan produk atau jasa tersebut kepada orang lain. Sehingga, kepercayaan mereka terhadap suatu produk akan meningkat karena adanya rekomendasi dari teman atau kerabatnya.

3) Buat usaha yang unik dan menarik, dengan demikian menarik para pencari berita untuk meliput usaha. Liputan dari berbagai media, dapat meningkatkan minat masyarakat untuk menyebarluaskan sebuah informasi. Sehingga marketing Word of Mouth semakin meluas, karena masyarakat cenderung menyukai berita.

Menurut Valeri A Zeithml, A Parasuraman dan Leonard L Bery dalam buku Freddy Rangkuti (2006:35), ada faktor-faktor yang mempengaruhi dalam upaya tingkat kinerja yang diharapkan akan diterima oleh pelanggan dimana merupakan suatu gabungan dari kepercayaan pelanggan akan apa yang dapat dan harus diterima (Desired Service), diantaranya:

1) Adanya keinginan untuk dilayani dengan baik dan benar. Pelanggan berharap dapat dilayani dengan baik karena dia melihat pelanggan lainnya dilayani dengan baik serta dilayani dengan benar, dimana pelayanan yang benar tergantung pada falsafah individu yang bersangkutan.

2) Kebutuhan perorangan. Pelayanan yang diharapkan pelanggan karena kebutuhan pelayanan yang bersifat mendasar dan terikat dengan kesejahteraan pelanggan.

\section{Jurnal Manajemen Indonesia}


3) Janji secara langsung. Pelayanan yang diharapkan oleh pelanggan yaitu pelanggan yang dijanjikan mendapatkan pelayanan secara langsung oleh pemberi/perusahaan.

4) Adapun janji yang secara tidak langsung. Pelayanan yang diharapkan pelanggan karena pelanggan memperoleh petunjuk yang berkaitan dengan pelayanan tersebut sehingga dia menarik kesimpulan tentang pelayanan seperti apayang seharusnya diberikan. Petunjuk tersebut meliputi harga serta peralatan pendukung pelayanan.

5) Komunikasi Word of Mouth, yaitu pelayanan yang didapatkan pelanggan karena pelanggan menerima informasi atau pernyataan yang telah disampaikan oleh pihak lain, misalnya individu, orang ahli, laporan pelanggan, serta publisitas.

6) Pegalaman masa lalu, yaitu pelayanan yang diharapkan oleh pelanggan karena telah memiliki pengalaman yang meliputi hal-hal yang telah dipelajarinya atau diketahuinya.

\subsection{Minat Menjadi Anggota Baitul Tamwil Muhammadiyah}

Ada beberapa pengertian minat menurut para ahli seperti dikatakan minat adalah merupakan suatu kesukaan, kegemaran atau kesenangan akan sesuatu obyek yang dipelajari (Sukardi, 2003: 61). Minat merupakan daya yang mendorong seseorang untuk melakukan sesuatu kegiatan. Pendapat lain mengatakan bahwa minat adalah kesukaan, (kecenderungan hati) kepada sesuatu (Nasution, 2004:76). Minat adalah kecenderungan yang menetap untuk memperhatikan dan mengenang beberapa aktivitas. Seseorang yang berminat terhadap aktivitas akan memperhatikan aktivitas itu secara konsisten dengan rasa senang (Syaiful Bahri Djamarah, 2008:132). Slameto (2010:180) menyatakan bahwa minat adalah suatu rasa lebih suka dan rasa ketertarikan pada suatu hal atau aktivitas, tanpa ada yang menyuruh.

\subsection{Jenis-Jenis Minat}

Banyak ahli yang mengemukakan mengenai jenis-jenis minat. Diantaranya Carl Safran (dalam Sukardi, 2003) mengklasifikasikan minat menjadi empat jenis yaitu:

1) Expressed interest, minat yang diekspresikan melalui verbal yang menunjukkan apakah seseorang itu menyukai dan tidak menyukai suatu objek atau aktivitas;

2) Manifest interest, minat yang disimpulkan dari keikutsertaan individu pada suatu kegiatan tertentu;

3) Tested interest, minat yang disimpulkan dari tes pengetahuan atau keterampilan dalam suatu kegiatan;

4) Inventoried interest, minat yang diungkapkan melalui inventori minat atau daftar aktivitas dan kegiatan yang sama dengan pernyataan.

Sedangkan menurut Moh. Surya (2004) mengenai jenis minat, menurutnya minat dapat dikelompokkan menjadi 3 jenis, yaitu sebagai berikut:

1) Minat volunter adalah minat yang timbul dari dalam diri siswa tanpa ada pengaruh luar;

2) Minat involunter adalah minat yang timbul dari dalam diri siswa dengan pengaruh situasi yang diciptakan oleh guru;

3) Minat non-volunter adalah minat yang ditimbulkan dari dalam diri siswa secara dipaksa atau dihapuskan.

Dilihat dari jenisnya atau macamnya ternyata minat menurut para ahli sangat beragam, akan tetapi sisi lain para ahli sepakat bahwa minat itu adalah kecenderungan atau dorongan yang muncul dalam hati atau keinginan terhadap sesuatu sesuai dengan kebutuhan yang diperlukan. Selain itu minat juga dipengaruhi oleh faktor yang muncul dari diri sendiri dan faktor dari luar 
atau lingkungan dimana seseorang berada. Dengan kata lain minat seseorang terhadap sesuatu tidak terlepas dari pengalaman dan pengetahuan yang dia miliki.

\section{JURNAL}

MANAJEMEN

INDONESIA

\section{Vol.17 No.3}

Desember 2017

\subsection{Keputusan Menjadi Anggota Baitul Tamwil Muhammadiyah (BTM)}

Ada beberapa pengertian yang dikemukakan oleh para ahli terkait dengan keputusan, salah satunya menurut Kotler (1997) keputusan adalah sebuah proses pendekatan penyelesaiaan masalah yang terdiri dari pengenalan masalah, mencari informasi, beberapa penilaian alternatif, membuat keputusan, membeli dan prilaku setelah membeli yang dilalui konsumen. Pendapat di atas memberikan pemahaman bahwa ketika seseorang akan memberikan keputusan atas segala sesutu yang menjadi pilihannya, maka sebagai tahapan yang bisa dilakukan adalah pertama melakukan pengenalan masalah atau pemecahan masalah sebagai proses awal yang digunakan untuk memilih suatu tindakan, kedua mengumpulkan informasi, ketiga melakukan evaluasi, keempat memutuskan untuk membeli atau mengambil dan kelima prilaku setelah memutuskan membeli. Pendapat lain mengatakan bahwa keputusan adalah semua prilaku yang memungkinkan digunakan untuk memecahkan persoalan dan menilai pilihan-pilihan secara sistematis dan objektif serta sasarannya yang menentukan keputusan serta kerugiannnya masing-masing, Drumond (2007:251). Berangkat dari pendapat di atas maka, paling tidak ada lima tahapan bagi seseorang ketika akan mengambil sebuah keputusan yaitu:

1) Pengenalan masalah dan pemecahan masalah

Sebagai tahap awal dalam sebuah keputusan adalah melakukan pengenalan terhadap sesuatu yang menjadi pilihannya, proses ini juga sekaligus sebagai proses pemecahan masalah untuk menemukan beberapa alternatif yang akan dipilih untuk diambil suatu tindakan. Biasanya dalam proses pengenalan masalah diawali dengan pertanyaan apakah masalah itu, mengapa masalah itu diperlukan dan bagiamana masalah itu bisa dimanfaatkan. Proses pengenalan masalah dapat dilakukan melalui tahapan pemecahan masalah.

2) Mengumpulkan informasi

Tahap kedua dalam sebuah keputusan adalah mengumpulkan informasi. Tahap ini dilakukan dalam upaya untuk mencari jawaban dari berbagai pertanyaan mengenai masalah itu. Informasi yang diperoleh sebagai dasar penguat bagi seseorang dalam mengambil sebuah keputusan. Informasi yang dikumpulkan sekaligus menjadi pengetahuan yang berharga untuk menentukan pilihan tepat atau tidaknya langkah yang akan di ambil. informasi ini diperoleh sebagai hasil musyawarah melalui suatu proses kegiatan rutin yang diadakan dalam suatu kelembagaan.

3) Melakukan evaluasi

Langkah ini sebagai upaya untuk meninjau kembali informasi atau data yang diperoleh, hal ini dimaksudkan apakah data atau informasi ini sudah cukup dan berkualitas atau masih memerlukan tambahan, disinilah dilakukan penilaian terhadap data informasi mengenai masalah yang sedang dihadapi. Tahap ini dilakukan untuk memberikan jaminan terhadap suatu tindakan yang akan diputuskan, sehingga hasilnya dapat memberikan kepuasaan dan satu sama lain bisa menerima.

4) Memutuskan untuk membeli atau mengambil

Tahap ini dianggap penting ini sebagai ancang-ancang untuk mengambil sebuah keputusan menerima, membeli atau mengambil sesuatu yang telah didukung dengan berbagai data informasi yang terkumpul. Atas dasar pertimbangan (logika), kemudian memilih anternatif salah satu yang terbaik, prioritas tujuan yang ingin dicapai, sehingga keputusan yang diambil semakin mendekat pada maksud atau tujuan yang dinginkan. Tahap ini termasuk pelaksanaan dari tahapan sebelumnya sebagai langkah terakhir dari tahapan pengambilan keputusan. 


\section{5) Prilaku setelah memutuskan membeli}

Pada tahapan kelima ini sebagai alat ukur baik bagi seseorang secara individu maupun kelompok, tentang kelanjutan terhadap sebuah hasil keputusan yang diambil. Apakah keputusan itu melahirkan produk dan meningkatkan kinerja? Tahap inilah yang menjadi ukuran terhadap sebuah keputusan yang diambil.

Atas dasar hasil pemikiran di atas, maka yang dimaksud keputusan menjadi anggota Baitul Tamwil Muhammadiyah (BTM) Kota Bandar Lampung adalah proses pengambilan keputusan untuk menjadi anggota atau nasabah baitul tamwil muhammadiyah setelah yang bersangkutan melakukan, pengenalan masalah, pencarian informasi, melakukan evaluasi sampai memutuskan sesuatu yang akan diambil untuk menjadi anggota dan memberdayakannya, guna memperoleh manfaat dan keuntungan.

\subsection{Baitul Tamwil Muhammadiyah (BTM)}

Menurut bahasa, istilah Bank dalam literatur Islam tidak dikenal. Baitul Tamwil berasal dari gabungan dua pengertian, yaitu Bait yang artinya rumah dan Tamwil (pengembangan harta kekayaan) yang asal katanya Maal atau harta. Secara keseluruhan Baitul Tamwil dimaknai sebagai tempat untuk mengembangkan usaha atau tempat untuk mengembangkan harta kekayaan. Pengertian dua suku kata itulah yang kemudian digunakan sebagai penamaan untuk lembaga keuangan mikro, yaitu berfungsi sebagai lembaga pengembangan usaha.

Secara defacto Baitut Tamwil Muhammadiyah (BTM) telah ada sejak bulan Februari 2004, meskipun pada waktu itu namanya belum koperasi melainkan Lembaga Keuangan Syariah (LKS). Ini ditandai dengan mulainya kegiatan pembiayaan pada pedagang-pedagang kecil yang ada di pasar tradisional Way Halim-Bandar Lampung. BTM didirikan oleh warga Muhammadiyah beranggotakan orang perorang (bukan badan hukum) yang bisa seluruhnya atau sebagian di antaranya adalah Persyarikatan Muhammadiyah, dan beroperasi di lingkungan Muhammadiyah, dimana terdapat para pengusaha kecil dan mikro yang menjadi anggotanya. Oleh karena itu, Baitul Tamwil Muhammadiyah dapat melayani seluruh lapisan masyarakat. Ini sebagai bukti konsep rahmatan lil'alamiin Muhammadiyah sebagai upaya membiayai usaha mikro berdasar pada prinsip syariah.

Untuk menjaga ruh atau idiologi Muhammadiyah, pengurus dan pengawas Baitul Tamwil Muhammadiyah merupakan representasi Muhammadiyah. Aturan ini tidak boleh tertera di dalam Anggaran Dasar Baitul Tamwil Muhammadiyah tetapi dapat diatur dalam Anggaran Rumah Tangganya. Di samping kepemilikan melalui perseorangan, Muhammadiyah akan mendapat bagian dari laba/sisa hasil usaha setiap tahun sebagai syirkah wujuh dan dana dana dakwah Baitul Tamwil Muhammadiyah atau sejenis Corporate Social Responsibility.

Baitul Tamwil Muhammadiyah, adalah Lembaga Keuangan Mikro yang beroperasi berdasarkan prinsip-prinsip syariah. Prinsip syariah artinya, semua transaksi keuangan dilakukan dengan akad sesuai prinsip dalam UU No 21 Tahun 2008 tentang Perbankan Syariah. Setelah sektor perbankan sukses menerapkan konsep syariah yang dimotori oleh Bank Muamalat Indonesia (BMI), kini konsep tersebut mulai merambah sektor ekonomi lainnya seperti asuransi, pasar modal, obligasi, reksadana, pegadaian dan pasar uang. Tidak tertutup kemungkinan konsep syariah juga akan mewarnai bisnis disektor riil, termasuk kalangan pelaku Usaha Mikro, Kecil, Menengah dan Koperasi (UMKMK) (Abdad, 2003).

\subsection{Produk Pembiayaan Keuangan Syariah}

Menurut SK Menteri Keuangan RI No. 792 Tahun 1990, lembaga keuangan adalah semua badan yang kegiatannya bidang keuangan, melakukan penghimpunan dan penyaluran dana kepada masyarakat terutama guna membiayai investasi perusahaan. Pasal 1 Undang-Undang No. 21 tahun 2008 tentang Perbankan Syariah, bank adalah badan usaha yang menghimpun 
dana masyarakat dalam bentuk simpanan dan menyalurkannya kepada masyarakat dalam bentuk kredit dan/atau bentukbentuk lainnya dalam rangka meningkatkan taraf hidup rakyat banyak. Bank terdiri dari dua jenis yaitu bank konvesional dan bank syariah. Bank konvesional adalah bank yang menjalankan kegiatan usahanya secara konvensional, yang terdiri atas bank umum konvensional dan Bank Pengkreditan Rakyat (BPR) sedangkan bank syariah adalah bank yang menjalankan kegiatan usahanya berdasarkan prinsip syariah yang terdiri atas Bank Umum Syariah (BUS) dan Bank Pembiayaan Rakyat Syariah (BPRS).

Ada prinsip yang dikembangkan dalam lembaga keuangan syariah, prinsip ini merupakan upaya untuk mempromosikan sekaligus mengembangkan nilai-nilai Islam yang berhubungan dengan kegiatan perbankan. Prinsip syariah yang dianut dan dikembangkan serta dilandasi oleh nilai-nilai keadilan kemanfaatan dan keseimbangan. Ada lima prinsip nilai-nilai Islam yang dikembangkan oleh bank syariah Islam, yaitu : (a) al-Ta'awun, yaitu prinsip saling membantu dan bekerjasama dengan anggota, (b) al-Iktinaz, yaitu menahan uang atau dana membiarkanny amenganggur dan tidak berputar dalam transaksi yang bermanfaat, (c) Masyir, yaitu mengundi nasib dan setiap kegiatan sifatnya untung-untungan, (d) Gharar, yaitu sesuatu yang memperdayakan manusia dalam bentuk harta, kemegahan, jabatan, syahwat dan lain-lain, (e) Haram, yaitu apapun perbuatan yang dilarang oleh Allah, (f) Riba penambahan pendapatan secara tidak sah (Islahi dan Thayib, 1997:153).

Bank syariah adalah bank yang berazaskan antara lain azas keadilan, azas kemitraan, azas transparansi dan azas universal. Serta melakukan usaha perbankan berdasarkan prinsip syariah. Kegiatan bank syariah merupakan implementasi dari prinsip ekonomi Islam dengan karakteristik antara lain sebagai berikut:

1) Pelarangan riba dalam berbagai bentuk;

2) Tidak mengenal konsep nilai waktu dari uang (time value of money); Konsep uang sebagai alat tukar bukan sebagai komoditas;

3) Tidak diperkenankan melakukan kegiatan yang bersifat spekulatif;

4) Tidak diperkenankan menggunakan dua harga untuk satu barang;

5) Tidak diperkenankan dua transaksi dalam satu akad;

Berangkat dari pemikiran tersebut, maka bank syariah mempunyai karakteristik sebagai ciri khas dalam menjalankan usahanya yang lebih mengedepankan aspek nilai kehalalan suatu transaksi atau produk yang ditawarkan dan aspek kemanfaatan yang bisa diambil oleh para pelaku yang ada didalamnya. Seperti telah dijelaskan dalam undang-undang bahwa bank syariah dibangun atas azas keadilan, kemitraan, transparansi dan universal. Untuk lebih jelasnya penulis jelaskan ke empat azas tersebut:

\section{Azas Keadilan}

Islam diturunkan ke alam dunia untuk dijadikan pedoman oleh manusia dalam menjalankan tugas dan fungsinya sebagai hamba Allah dan kholifah. Dalam bidang ekonomi, prinsip keadilan dapat dikategorikan kedalam beberapa hal, antara lain: a. seseorang mendapatkan sesuatu sesuai dengan hasil jerih payahnya. b. Pendistribusian kesejahteraan secara merata (keadilan sosial) c. Berbagi untung dan resiko (Suganda, 2011:21). Dalam konteks al-Quran banyak sekali ayat-ayat yang terkait dengan perintah menegakkan keadilan, Firman Allah SWT:

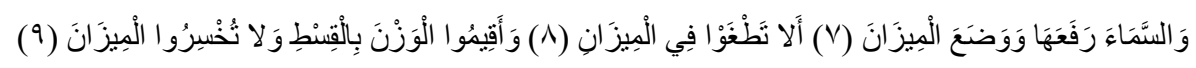

Artinya: "Dan Allah Telah meninggikan langit dan Dia meletakkan neraca (keadilan). Supaya kamu jangan melampaui batas tentang neraca itu. Dan Tegakkanlah timbangan itu dengan adil dan janganlah kamu mengurangi neraca itu". (QS Ar Rahman:7-9).

\section{Jurnal Manajemen Indonesia}


Ada beberapa hal yang bisa diambil kesimpulan dari ayat di atas, yaitu bahwa para nabi dan rasul diutus oleh Allah ke muka bumi adalah salah satunya untuk menegakan keadilan dalam setiap aktivitas kehidupan termasuk masalah muamalah jual beli atau perdagangan. Penegakan keadilan dalam hal perdangan merupakan suatu solusi yang ditawarkan oleh Allah dalam mengatasi suatu perdangan atau jual beli yang saling merugikan. Salah satu hikmah dari perintah penegakan keadilan adalah supaya harta itu tidak beredar di kalangan orang kaya saja, tapi lebih mengedapankan pemerataan dan pertumbuhan yang disesuaikan dengan kondisi masyarakat, sehingga penegakan azas ini mampu menekan angka kemiskinan dan pengangguran.

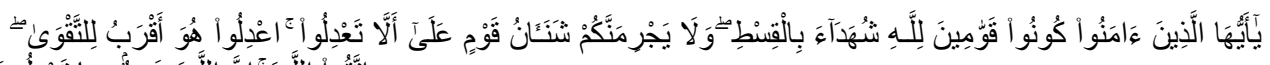

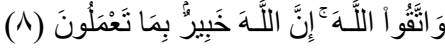

Artinya: "Hai orang-orang yang beriman hendaklah kamu jadi orangorang yang selalu menegakkan (kebenaran) Karena Allah, menjadi saksi dengan adil dan janganlah sekali-kalikebencianmu terhadap sesuatu kaum, mendorong kamu untuk berlaku tidak adil. Berlaku adillah, karena adil itu lebih dekat kepada takwa. Dan bertakwalah kepada Allah, Sesungguhnya Allah Maha mengetahui apa yang kamu kerjakan.” (QS. Al Maidah: 8)

Ayat ini menjelaskan bahwa Allah telah memerintahkan kepada umat manusia agar menegakkan keadilan dan tidak mengurangi timbangan. Ayat ini sangat erat kaitannya dengan masalah ekonomi terutama perdagangan. Dengan demikian, sistem yang harus dikembangkan dalam usaha ekonomi itu adalah syariah, yang salah satu prinsipnya adalah keadilan.

Bagi pelaku ekonomi dalam Islam telah diatur sistemya dengan mengedepankan prinsipprinsip yang sesuai dengan syariah. Ekonomi yang dikembangkan adalah perdagangan yang menguntungkan sekaligus dapat menyelamatkan dari kehancuran ekonomi. Maka dalam Islam menjadi suatu keharusan apabila manusia ingin selamat dalam melakukan perdagangannya, maka syaratnya harus memiliki pengetahuan tentang keimanan, mampu melaksanakan dalam kehidupan sehari-hari dengan sungguh-sungguh baik dengan harta, jiwa maupun tenaga. Hal ini sesuai dengan Firman Allah:

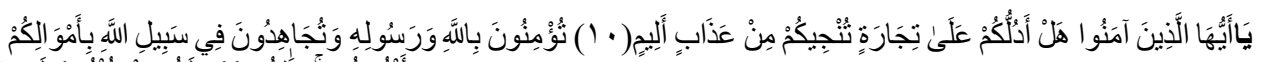

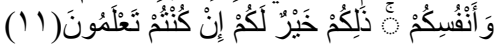

Artinya: "Wahai orang -orang yang beriman maukah Aku tunjukan suatu bisnis yang dapat menguntungkan, menyelamatkan dari azab yang pedih? Yaitu kamu beriman kepada Allah dan Rosul-Nya dan berjihad dijalan Allah dengan harta dan jiwamu. Itulah yang lebih baik bagimu jika kamu mengetahuinya." (QS. AsShaff:10-11)

Ada tiga amalan yang dapat menyelamatkan hidup manusia yaitu beriman kepada Allah, artinya taat dan tunduk melaksanakan perintah-Nya dan menjauhi larangan-Nya, mengikuti jalan hidupnya berdasarkan contoh dan prilaku para rasul sebagai utusan-Nya, disertai dengan bekerja dan mengimplementasikan dengan sunguh-sungguh dalam kehidupan sehari-hari apa yang telah diperintahkan dan dicontohkan oleh para rasul, baik dengan harta maupun jiwa.

Atas dasar uraian di atas maka keadilan yang dimaksud dalam adalah bagi pelaku ekonomi atau perdagangan yang terjadi dikalangan manusia maka yang harus dibangun sebagai azas kegiatan ekonomi adalah dengan menegakkan keadilan. Sikap ini akan menjamin kemaslahatan dunia akhirat dan saling menguntungkan satu sama lain. 


\section{Azas Kemitraan}

Suatu bisnis yang dilandasi dengan kemitraan, maka akan melahirkan suatu tatanan usaha

JURNAL

MANAJEMEN

INDONESIA

\section{Vol.17 No.3}

Desember 2017 atau bisnis yang mendatangkan keberkahan serta kemanfaatan dan terhindar dari perpecahan satu sam lain. Azas kemitraan ini lebih mengedepankan saling membutuhkan, saling mendukung dan saling menguntungkan. Kemitraan yang dibangun dalam produk lembaga keuangan syariah pada Baitul Tamwil Muhammadiyah adalah sebagai sarana untuk meningkatkan pendapatan usaha kecil dimasyarakat, sehingga pendapatan mereka bertambah, terjadi pemberdayaan masyarakat, pertumbuhan ekonomi meningkat, lapangan kerja tersedia.

Ada beberapa bentuk kemitraan yang dikembangkan sebagai produk lembaga keuangan syariah, sebagaimana dikemukakan oleh Muhammad (2006:20) produk dan jasa bank syariah yang ditawarkan adalah sebagai berikut:

a. Al-wadi'ah (Simpanan)

b. Pembiayaan Dengan Bagi Hasil

1) Al-musyarakah (Partisipasi Modal)

2) AI-Mudharabah

Dalam praktiknya mudharabah terbagi menjadi 2 macam, yakni: Mudharabah muthlaqahdan Mudharabah muqayyadah,

3) Al-Muzara'ah

4) Al-Musaqah

c. Bai' Al-Murabahah (jual beli)

d. Bai'Salam

e. Bai' Al-Istishna'

f. Al-ijarah (Sewa)

g. Al-wakalah (Amanat)

h. Al-Kafalah (Garansi)

i. Al-Hawalah

j. $\quad A r-R a h n$

3. Azas Transparansi

Azas ini menjadi dasar bagi suatu usaha atau bisnis dalam suatu kelompok yang sedang menjalankan bisnisnya. Konsep yang dikembangkannya adalah jujur, benar, akuntabilitas, dan amanah. Hal ini sejalan dengan pemikiran Agustianto dalam https://shariaeconomics.wordpress.com, diakses tanggal 10/05/2017 mengatakan bahwa semua dana yang diperoleh dalam sistem perbankan syariah dikelola dengan integritas tinggi yaitu dengan mengedepankan nilai-nilai Siddiq, Tablig, Amanah dan Fathonah.

4. Azas Universal

Universal artinya menyeluruh, maksudnya bahwa suatu konsep bisa berlaku untuk semua.

\section{Kajian Literatur}

Perlu penulis sampaikan perbedaan rencana penelitian ini dengan penelitian sebelumnya sebagai berikut:

\section{Jurnal Manajemen Indonesia}


a. Penelitian Maru File dkk. (1994) mengatakan bahwa masukan sebagai (input) dan produk sebagai (output) Word of Mouth dapat mempengaruhi terhadap minat atau keinginan seseorang untuk melakukan pembelian secara berulang mengenai sesuatu produk yang diinginkan. Penelitian yang akan dilakukan ingin mengetahui pengaruh strategi marketing Word of Mouth dan produk keuangan syariah terhadap minat menjadi Nasabah. Objek penelitian sebelumya adalah minat terhadap hotel sedangkan penelitian ini minat menjadi nasabah Baitul Tamwil Muhammadiyah.

b. Perbedaan penelitian Aflit Nuryulia Praswati (2009). Hasil penelitian ini adalah proses dasar yang mempengaruhi dan dipengaruhi oleh komunikasi Word of Mouth menghasilkan proses yang signifikan. Komunikasi Word of Mouth dapat dicapai melalui peningkatan kualitas pelayanan, kepuasan pelanggan, komitmen dan kekuatan hubungan yang pada akhirnya komunikasi Word of Mouth itu dapat mendorong minat, selain itu juga penelitian ini ingin mencari faktor-faktor yang mempengaruhi strategi marketing Word of Mouth, sedangkan penelitian yang akan dilakukan ini ingin mencari seberapa jauh pengaruh Word of Mouth dan produk keuangan terhadap minat menjadi nasabah Baitul Tamwil Muhammadiyah.

c. Perbedaan penelitian Ng dkk. (2011). Hasil penelitian ini menyebutkan bahwa Fungsional quality dan relationship quality dapat memainkan peran penting dalam menghasilkan suatu prilaku word of mouth. Sedangkan penelitian yang akan dilakukan ini ingin menemukan pengaruh strategi marketing word of mouth dan produk keuangan syariah terhadap minta menjadi nasabah di Baitul Tamwil Muhammadiyah.

d. Perbedaan penelitian Salina Kassim (2016). Hasil penelitian ini mengatakan bahwa strategi untuk memastikan keberhasilan Baitul Maal wat-Tamwil diantaranya dengan menjaga stabilitas subsidi demi menjaga keberlanjutan Baitul Maal wat-Tamwil, pembiayaan kreditplus dengan financing yang tepat sasaran, infrastruktur yang memadai dan traning yang mendukung untuk terus menjadi nasabah. Jadi penelitian ini lebih ditekankan pada strategi mempertahankan terus menjadi nasabah, sedangkan penelitian yang akan dilakukan ingin menemukan sekaligus menganalisis tentang faktor yang mempengaruhi minat menjadi nasabah Baitul Tamwil Muhammadiyah.

e. Perbedaan penelitian Ajija, (2015) hasil penelitian ini mengatakan bahwa faktor yang dapat meningkatkan pendapatan para nasabah Baitul Maal wat-Tamwil setelah melakukan pembiayaan. Sedangkan penelitian yang akan dilakukan ini lebih kepada menemukan apakah minat menjadi nasabah Baitul Tamwil Muhammadiyah dapat dipengaruhi oleh strategi marketing Word of Mouth dan produk lembaga keuangan syariah.

Berangkat dari hasil kajian literatur baik hasil penelitian maupun teori-teori para ahli tentang Word of Mouth, maka peneliti menyimpulkan bahwa Word of Mouth merupakan strategi marketing yang akan menentukan tingkat keberhasilan pemasaran yang ditunjukkan oleh rasa puas para nasabah atau konsumen untuk menentukan pilihan produk sesuai dengan keinginan. Dengan demikian strategi marketing Word of Mouth dapat berpengaruh terhadap minat seseorang. 


\section{Kerangka Pemikiran}

\section{JURNAL}

\section{MANAJEMEN}

INDONESIA

\section{Vol.17 No.3}

\section{Desember 2017}

Gambar 1. Kerangka Pemikiran Pengaruh Pemasaran Word of Mouth dan Produk pembiayaan Syariah Terhadap Minat dan Keputusan Nasabah Pada Baitul Tamwil Muhammadiyah (BTM) Kota Bandar Lampung

Tabel 1. Komposisi Besar Sampel Berdasarkan Wilayah usaha

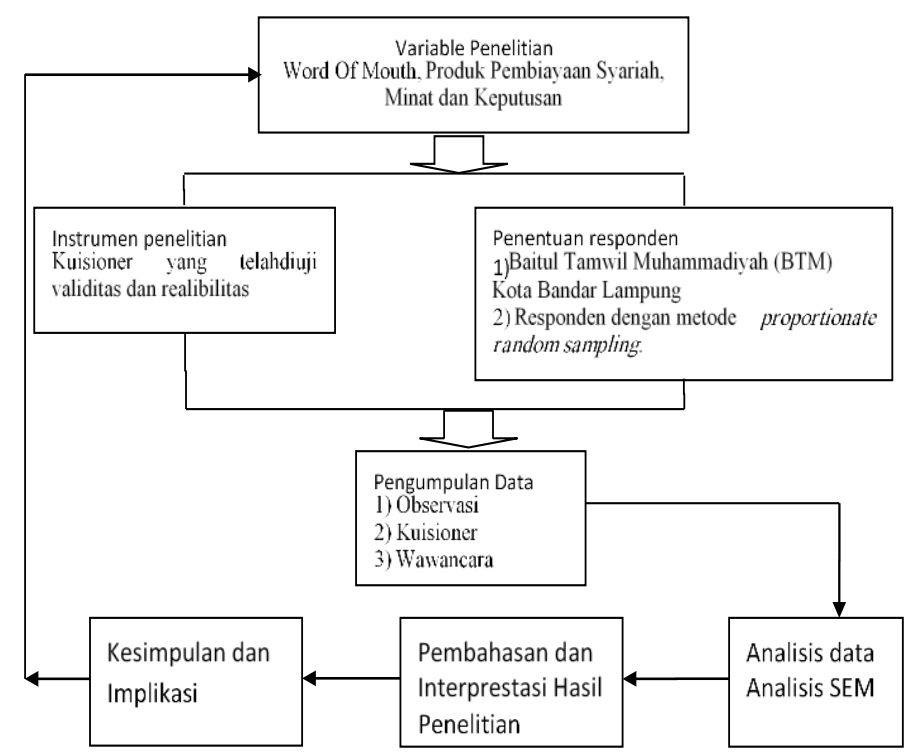

\section{Metode Penelitian}

\subsection{Desain Penelitian}

Berdasarkan rancangan penelitian, maka ada empat variabel yang akan diteliti, yaitu pemasaran Word of Mouth, produk lembaga syariah, minat dan keputusan. Selanjutnya untuk menentukan instrumen berdasarkan variabel penelitian dan kemudian menentukan sampel. Pengumpulan data dilakukan dengan metode observasi, wawancara dan kuisioner. Data yang terkumpul diolah dengan menggunakan alat analisis deskriptif kualitatif dan kuantitatif. Teknik analisa yang dipergunakan untuk menganalisis data adalah analisis SEM (Structural Equation Model). Hasil analisa kemudian diinterpretasikan dan langkah terakhir disimpulkan serta diberikan saran.

\subsection{Populasi dan Sampel Penelitian}

\begin{tabular}{|c|c|c|}
\hline No & Wilayah Usaha & Jumlah Responden (Orang) \\
\hline 1 & Pasar Way halim & $\mathbf{2 0}$ \\
\hline 2 & Pasar Sukarame & $\mathbf{2 9}$ \\
\hline 3 & Pasar Way Kandis & $\mathbf{2 0}$ \\
\hline 4 & Pasar Tugu & $\mathbf{1 0}$ \\
\hline & Jumlah & $\mathbf{7 9}$ \\
\hline
\end{tabular}

\subsection{Data dan Sumber Data}

Data dipergunakan dalam penelitian ini adalah sebagai berikut. 1) Data kuantitatif, yaitu data yang dinyatakan dalam bentuk angka-angka yang dapat dihitung; 2) Data kualitatif, yaitu data yang tidak dapat dinyatakan dalam bentuk angka-angka, seperti jawaban responden tentang tanggapannya terhadap Baitul Tamwil Muhammadiyah, termasuk data keberadaan lokasi penelitian dan sumber-sumber lain yang bisa digali datanya tentang nasabah Baitul Tamwil Muhammadiyah Kota Bandar Lampung.

\section{Jurnal Manajemen Indonesia}




\subsection{Uji Instrument Penelitian}

Menurut Suharsimi Arikunto (1989:135) menjelaskan bahwa benar atau tidaknya data tergantung dari baik tidaknya instrumen pengumpul data. Intrumen yang baik harus memenuhi dua persyaratan penting, yaitu valid dan reliabel.

\subsection{Teknik Pengumpulan Data}

Ada beberapa alat pengumpul data yang digunakan dalam penelitian ini yaitu: observasi, kuisioner, wawancara. Wawancara dilakukan dengan anggota dan pegawai, adapun data yang diperlukan adalah bagaimana tanggapan responden terhadap program Baitul Tamwil Muhammadiyah Kota Bandar Lampung.

\subsection{Definisi Operasional Variabel Penelitian}

Untuk menghindari kesalahan dalam mengartikan variabel yang dianalisis, berikut ini dijelaskan definisi operasional dari masing-masing variabel sebagai berikut:

1) Variabel Word of Mouth (X1)

(X1.1) Membicarakan; (X1.2) Mendorong; (X1.3) Merekomendasikan.

2) Variabel Produk lembaga Syariah (X2)

(X2.1) Keadilan; (X2.2) Kemitraan; (X2.3) Transparansi; (X2.4) Universal.

3) Variabel Minat (Y1)

(Y1.1) Perasaan senang; (Y1.2) Memperhatikan; (Y1.3) Manfaat.

4) Variabel Keputusan (Y2)

(Y2.1) Pengenalan masalah; (Y2.2) Kegiatan mencari informasi; (Y2.3) Melakukan evaluasi; (Y2.4) Memutuskan untuk membeli; (Y2.5) Perilaku setelah memutuskan membeli.

\begin{tabular}{|c|c|c|c|c|}
\hline Variabel & Indikator & $\begin{array}{c}\text { Jumlah } \\
\text { Butir } \\
\text { Pernyataan } \\
\end{array}$ & $\begin{array}{c}\text { Butir } \\
\text { Pernyataan }\end{array}$ & Referensi \\
\hline \multirow{3}{*}{$\begin{array}{c}\text { Strategi } \\
\text { MarketingWord } \\
\text { Of Mouth }\left(\mathrm{X}_{1}\right) \\
\end{array}$} & Membicarakan & 7 & $1,2,3,4,5,6,7$ & \multirow{3}{*}{ Mix,2007 } \\
\hline & Mendorong & 5 & $8,9,10,11,12$ & \\
\hline & Merekomendasikan & 3 & $13,14,15$ & \\
\hline \multirow{4}{*}{\begin{tabular}{l}
\multicolumn{1}{c}{ Produk } \\
Pembiayaan \\
Syariah $\left(\mathbf{X}_{2}\right)$
\end{tabular}} & Keadilan & 6 & $1,2,3,4,5,6$ & \multirow{4}{*}{$\begin{array}{c}\text { Azas } \\
\text { Operasional } \\
\text { Bank Syariah } \\
\text { Pasal } 2 \text { UU } \\
\text { no. } 21\end{array}$} \\
\hline & Kemitraan & 5 & $7,8,9,10,11$ & \\
\hline & Transparansi & 2 & 12,13 & \\
\hline & Universal & 2 & 14,15 & \\
\hline \multirow{3}{*}{$\begin{array}{l}\text { Minat Menjadi } \\
\text { Nasabah (Y) }\end{array}$} & Perasaan Senang & 5 & $1,2,3,4,5$ & \multirow{3}{*}{$\begin{array}{l}\text { Slamaeto } \\
\text { 2010:180 }\end{array}$} \\
\hline & Memperhatikan & 5 & $6,7,8,9,10$ & \\
\hline & Manfaat & 5 & $11,12,13,14,15$ & \\
\hline \multirow{5}{*}{ Keputusan (Y) } & Pengenalan masalah & 3 & $1,3,5$ & \multirow{5}{*}{$\begin{array}{c}\text { Kotler } \\
1997\end{array}$} \\
\hline & Mencari informasi & 3 & $2,4,6$ & \\
\hline & Evaluasi & 3 & $7,9,11$ & \\
\hline & Memutuskan membeli & 3 & $8,10,12$ & \\
\hline & $\begin{array}{c}\text { Prilaku setelah } \\
\text { membeli }\end{array}$ & 3 & $13,14,15$ & \\
\hline
\end{tabular}

JURNAL

MANAJEMEN

INDONESIA

Vol.17 No.3

Desember 2017
Tabel 2.

Indikator Pengukuran 


\subsection{Teknik Analisis Data melalui Analisis SEM PLS (Structural Equation Model Partial Least Square)}

Model Persamaan Struktural atau Structural Equation Model (SEM) adalah teknik-teknik

JURNAL

MANAJEMEN

INDONESIA

\section{Vol.17 No.3}

Desember 2017
Gambar
2. Model
Struktural Pengaruh
Word of Mouth dan
Produk Syariah Terhadap
Minat dan Keputusan
Nasabah Baitul Tamwil
Muhammadiyah (BTM)
Kota Bandar lampung statistika yang memungkinkan pengujian suatu rangkaian hubungan yang relatif kompleks secara simultan. Hubungan yang kompleks dapat dibangun antara satu atau beberapa variabel dependen dengan satu atau beberapa variabel independen. Mungkin juga terdapat suatu variabel yang berperan ganda yaitu sebagai variabel independen pada suatu hubungan, namun menjadi variabel dependen pada hubungan lain mengingat adanya hubungan kausalitas yang berjenjang. Masing masing variabel dependen dan independen dapat berbentuk faktor atau konstruk yang dibangun dari beberapa variabel indikator. Demikian pula diantara variabel-variabel itu dapat berbentuk sebuah variabel tunggal yang diobservasi atau yang diukur langsung dalam sebuah proses penelitian.

\subsection{Konvensi SEM}

Beberapa konvensi atau aturan-aturan yang diberlakukan di dalam penggunaan SEM ini sebagai berikut:
1) Variabel terukur (Measured Variable)
2) Faktor
3) Hubungan antar variabel

\section{Hasil Dan Pembahasan}

\subsection{Hasil Penelitian}

\section{Data Responden Penelitian}

Berdasarkan hasil penyebaran angket kepada 79 responden diperoleh hasil seluruh responden tidak menjadi anggota/ nasabah ditempat lain. Dari ke 79 responden yang telah diteliti sebagian besar responden memiliki pekerjaan sebagai pedagang. 


\section{Uji Validitas Instrumen}

Hasil dari pengujian validitas terhadap instrumen pernyataan untuk variabel Word of Mouth $\left(X_{1}\right)$ dan Produk $\left(X_{2}\right)$ dapat diketahui bahwa seluruh item pernyataan untuk mengukur variabel Word of Mouth memiliki nilai Corrected Item-Total Correlation lebih besar dari $r_{\text {tabel }}=$ 0,444 . Dengan demikian dapat dikatakan bahwa keseluruhan item pernyataan mengenai variabel Word of Mouth tersebut valid dan dapat digunakan sebagai alat ukur penelitian.

Diketahui juga bahwa seluruh item pernyataan untuk mengukur variabel produk memiliki nilai Corrected Item-Total Correlation lebih besar dari $r_{\text {tabel }}=0,444$. Dengan demikian dapat dikatakan bahwa keseluruhan item pernyataan mengenai variabel produk tersebut valid dan dapat digunakan sebagai alat ukur penelitian.

Validitas untuk instrumen variabel dependen juga dilakukan yakni isntrumen pengukur variabel Minat dan Keputusan $\left(Y_{1}, Y_{2}\right)$. Dapat diketahui bahwa seluruh item pernyataan untuk mengukur variabel minat memiliki nilai Corrected Item-Total Correlation lebih besar dari $r_{\text {tabel }}=0,444$. Dengan demikian dapat dikatakan bahwa keseluruhan item pernyataan mengenai variabel minat tersebut valid dan dapat digunakan sebagai alat ukur penelitian. Diketahui bahwa seluruh item pernyataan untuk mengukur variabel keputusan memiliki nilai Corrected ItemTotalCorrelation lebih besar dari $r_{\text {tabel }}=0,444$. Dengan demikian dapat dikatakan bahwa keseluruhan item pernyataan mengenai variabel keputusan tersebut valid dan dapat digunakan sebagai alat ukur penelitian.

\section{Uji Reliabilitas Instrumen}

Instrumen dikatakan reliabel jika nilai alpha cronbach lebih besar dari 0,7.

a. Uji Reliabilitas Variabel Word of Mouth $\left(\boldsymbol{X}_{\mathbf{1}}\right)$

Uji reliabilitas didapatkan nilai alpha untuk variabel Word of Mouth $\left(X_{1}\right)$ sebesar 0,914 , artinya intrumen untuk mengukur Word of Mouth ini dapat digunakan untuk penelitian.

b. Uji Reliabilitas Variabel Produk $\left(\boldsymbol{X}_{2}\right)$

Berdasarkan hasil uji reliabilitas didapatkan nilai alpha untuk variabel Produk $\left(X_{2}\right)$ sebesar 0,933, artinya intrumen untuk mengukur produk ini dapat digunakan untuk penelitian.

c. Uji Reliabilitas Variabel Minat $\left(\boldsymbol{Y}_{\mathbf{1}}\right)$

Berdasarkan hasil uji reliabilitas didapatkan nilai alpha untuk variabel Minat $(Y)$ sebesar 0,945 , artinya intrumen untuk mengukur minat ini dapat digunakan untuk penelitian.

d. Uji Reliabilitas Variabel Keputusan $\left(\boldsymbol{Y}_{2}\right)$

Berdasarkan hasil uji reliabilitas didapatkan nilai alpha untuk variabel Keputusan $\left(Y_{2}\right)$ sebesar 0,920, artinya intrumen untuk mengukur keputusan ini dapat digunakan untuk penelitian.

\section{Analisis Data Penelitian}

a) Outer Model

Evaluasi Outer Model digunakan untuk mencari model terbaik. Apabila nilai outer loading kurang dari 0,4 maka indikator variabel harus dihilangkan. Gambar Path Model sebelum dievaluasi dapat dilihat pada Gambar 3. 


\section{JURNAL}

MANAJEMEN

INDONESIA

\section{Vol.17 No.3}

\section{Desember 2017}

Gambar 3. Path

Model Sebelum

Dievaluasi

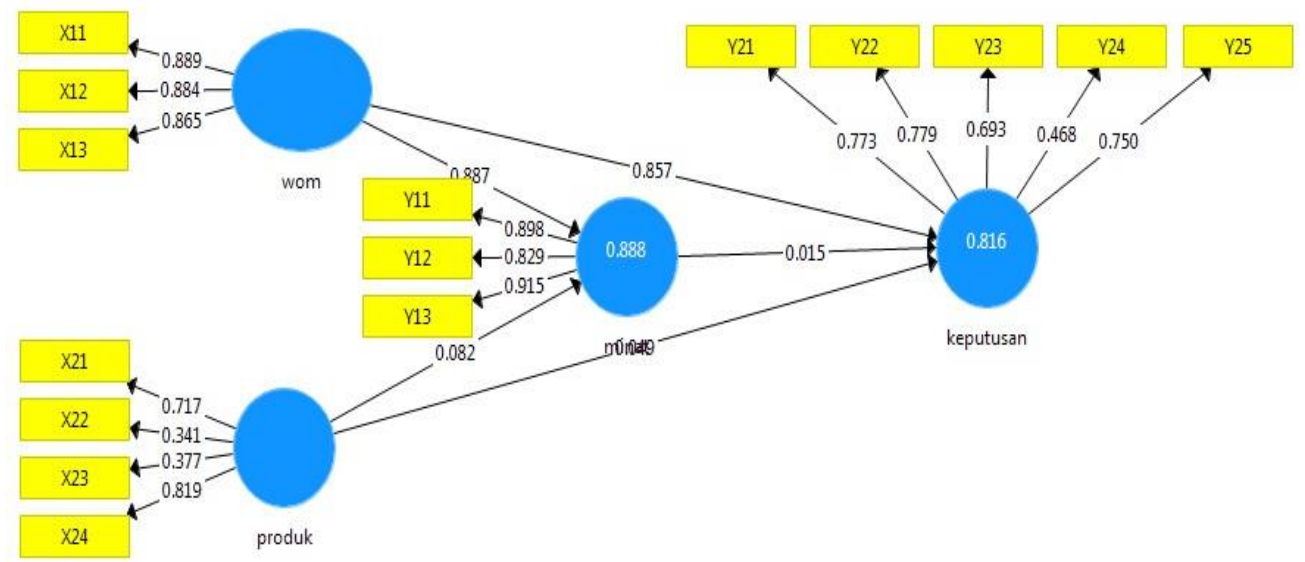

Berdasarkan Gambar 3 terlihat bahwa pada variabel independen 1 Word of Mouth (X1) seluruh nilai outer loading di atas 0,4 artinya seluruh indikator pada variabel Word of Mouth dapat digunakan. Pada variabel independen 2 produk (X2) nilai outer loading indikator kemitraan (X22) dan transparansi (X23) kurang dari 0,4 sehingga indikator kemitraan dan transparansi tidak digunakan dalam model. Variabel dependen 1 yakni variabel minat (Y1) seluruh nilai outer loading pada masing-masing indikator lebih dari 0,4 sehingga seluruh indikator masuk ke dalam model, dan pada variabel dependen 2 yakni variabel keputusan (Y2) seluruh nilai outer loading pada masing-masing indikator lebih dari 0,4 sehingga seluruh indikator masuk ke dalam model. Setelah dilakukan evaluasi gambar Path Model dapat dilihat pada Gambar 4.

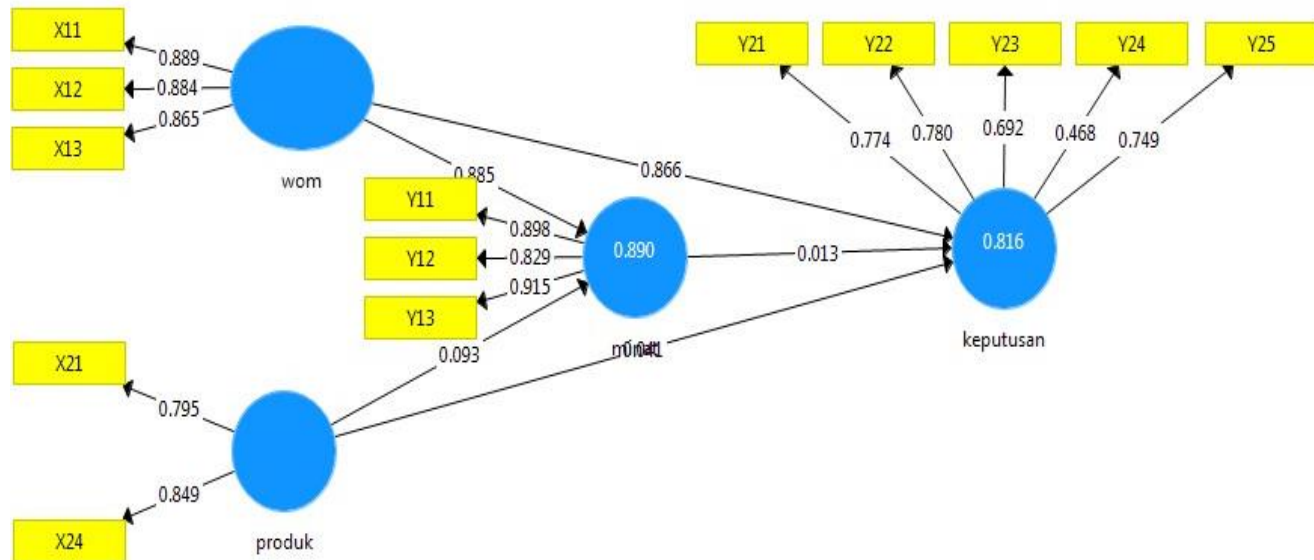

\section{b) Inner Model}

Evaluasi Inner Model dilakukan untuk menjelaskan pengaruh variabel laten independen terhadap variabel laten dependen. Hasil analisis data menggunakan software PLS dapat dilihat pada Gambar 5. 


\begin{tabular}{|c|r|r|r|r|r|} 
& Original Sampl... & Sample Mean $(\ldots$ & Standard Error ... & T Statistics $(\mid 0 . .$. & P Values \\
\hline minat $\rightarrow$ keput... & 0.013 & 0.017 & 0.225 & 0.058 & 0.954 \\
\hline produk $\rightarrow$ kep... & 0.041 & 0.037 & 0.075 & 0.555 & 0.579 \\
\hline produk $\rightarrow$ minat & 0.093 & 0.091 & 0.045 & 2.079 & 0.038 \\
\hline wom $\rightarrow$ keput... & 0.866 & 0.868 & 0.192 & 4.516 & 0.000 \\
\hline wom $\rightarrow$ minat & 0.885 & 0.888 & 0.032 & 27.515 & 0.000 \\
\hline
\end{tabular}

\section{JURNAL \\ MANAJEMEN \\ INDONESIA} 579

0.038

0.000

0.000
Vol.17 No.3

Desember 2017

Gambar 5. Hasil

Analisis Path dengan

PLS pengaruh yang positif Word of Mouth terhadap minat. Semakin tinggi Word of Mouth maka akan semakin tinggi juga minat nasabah. Pada kolom P Value nilainya 0,000 kurang dari 0,05 artinya ada pengaruh yang signifikan (berarti) Word of Mouth terhadap minat.

2) Pengaruh Word of Mouth terhadap keputusan

Pada Gambar 5, kolom original sample baris ketiga nilainya 0,866 artinya ada pengaruh yang positif Word of Mouth terhadap keputusan. Semakin tinggi Word of Mouth maka akan semakin tinggi juga keputusan nasabah. Pada kolom $\mathrm{P}$ Value nilainya 0,000 kurang dari 0,05 artinya ada pengaruh yang signifikan (berarti) Word of Mouth terhadap keputusan.

3) Pengaruh produk terhadap minat

Pada Gambar 5, kolom original sample baris kesatu nilainya 0,093 artinya ada pengaruh yang positif produk terhadap minat. Semakin tinggi produk maka akan semakin tinggi juga minat nasabah. Pada kolom $\mathrm{P}$ Value nilainya 0,038 kurang dari 0,05 artinya ada pengaruh yang signifikan (berarti) produk terhadap minat.

4) Pengaruh produk terhadap keputusan

Pada Gambar 5, kolom original sample baris kedua nilainya 0,041 artinya ada pengaruh yang positif produk terhadap minat. Semakin tinggi produk maka akan semakin tinggi juga minat nasabah. Pada kolom $\mathrm{P}$ Value nilainya 0,579 lebih dari 0,05 artinya tidak ada pengaruh yang signifikan (berarti) produk terhadap minat.

5) Pengaruh Minat terhadap keputusan

Pada gambar 5, kolom original sampel baris kedua nilainya 0,013 artinya ada pengaruh yang positif minat terhadap keputusan. Semakin tinggi minat maka akan semakin tinggi juga keputusan nasabah. Pada kolom P Value nilainya 0,954 lebih dari 0,05 artinya tidak ada pengaruh yang signifikan (berarti) minat terhadap keputusan.

\begin{tabular}{l|r|r|r|r|r|} 
& Original Sampl... & Sample Mean $(\ldots$ & Standard Error ... & T Statistics $(\mid 0 . .$. & P Values \\
\hline keputusan & 0.816 & 0.832 & 0.031 & 26.129 & 0.000 \\
\hline minat & 0.890 & 0.895 & 0.021 & 41.923 & 0.000 \\
\hline
\end{tabular}

Gambar 6. Pengujian Goodness of fit

Terlihat bahwa nilai $\mathrm{R}^{2}$ untuk variabel endogen minat sebesar 0,890 artinya keragaman data dapat dijelaskan oleh variabel Word of Mouth dan produk sebesar $89,0 \%$ sisanya dijelaskan oleh variabel yang lain. Nilai $\mathrm{R}^{2}$ untuk variabel endogen keputusan sebesar 0,816 artinya keragaman data dapat dijelaskan oleh variabel Word of Mouth dan produk sebesar $81,6 \%$ sisanya dijelaskan oleh variabel yang lain. 


\subsection{Pembahasan}

\section{JURNAL}

MANAJEMEN

INDONESIA

\section{Vol.17 No.3}

Desember 2017
Berdasarkan hasil penelitian variabel-variabel laten independent dalam penelitian ini meliputi variabel Word of Mouth dan variabel produk pembiayaan syariah. Variabel word of mouth yang dalam peneilitian ini diukur berdasarkan in dikator-indikator yang digunakan dalam instrumen angket meliputi indikator membicarakan, mendorong dan merekomendasikan. Setelah dilakukan analisis dengan menggunakan analisis SEM (Struktural Equation Model), pada langkah outer model diperoleh hasil untuk variabel Word of Mouth yang diukur berdasarkan indikator membicarakan, mendorong, dan merekomendasikan diperoleh hasil ketiga indikator ini dapat digunakan seluruhnya untuk mengukur variabel Word of Mouth. Hal ini dikarenakan besarnya outer loading dari ketiga indikator ini di atas 0,4, sehingga dapat disimpulkan bahwa faktor konfirmatori konstruk variabel Word of Mouth yang meliputi indikator membicarakan, mendorong, dan merekomindasikan dapat digunakan untuk mengukur besarnya variabel Word of Mouth.

Variabel laten independen lainnya dalam penelitian ini adalah variabel produk pembiayaan syari'ah. Berdasarkan hasil analisis SEM (Struktural Equation Model) dalam langkah outer model indikator-indikator yang mengukur variabel produk dalam penelitian ini yang meliputi keadilan, kemitraan, transparansi, dan universal yang dapat digunakan dalam mengukur variabel produk dalam penelitian ini hanya indikator keadilan dan universal. Sehingga faktor konfirmatori konstruk variabel produk untuk indikator kemitraan dan transparansi tidak dapat digunakan untuk mengukur variabel produk pembiayaan syari'ah.

Pada langkah outer model selanjutnya untuk variabel laten dependent dalam penelitian ini yakni variabel minat dan variabel keputusan. Berdasarkan hasil analisis SEM (Struktural Equation Model) pada langkah outer diperoleh hasil untuk variabel produk yang awalnya dirancang diukur berdasarkan indikator Perasaan senang, Memperhatikan, dan Manfaat seluruh nilai outer loading untuk variabel produk ini melebihi 0,4 . Artinya seluruh indikator yang dirancang awal untuk mengukur variabel produk dalam penelitian ini dapat digunakan semua. Sedangkan untuk variabel keputusan yang awalnya dirancang diukur dengan meliputi indikator pengenalan masalah, kegiatan mencari informasi, melakukan evaluasi, memutuskan untuk membeli, dan perilaku sikap setelah memutuskan membeli seluruh nilai outer loading melebihi 0,4 . Sehingga untuk variabel keputusan faktor konfirmasi kontrak yang digunakan dalam penelitian dapat digunakan seluruhnya.

Analsis SEM (Struktural Equation Model) tahap selanjutnya yaitu Inner Model, dimana ditahap ini mulai menganalisis terdapat pengaruh atau tidaknya antara variabel laten independen dan variabel laten dependen. Hasil analisis SEM pada tahap ini memperoleh hasil diantaranya untuk variabel laten dependen Word of Mouth dengan variabel laten dependen minat diperoleh kesimpulan variabel Word of Mouth memberikan pengaruh positif terhadap variabel minat. Artinya semakin tinggi nilai variabel Word of Mouth maka semakin tinggi variabel minat.

Sehingga dapat disimpulkan strategi pemasaran melalui Word of Mouth sangat mempengaruhi minat pelanggan. Dengan kata lain semakin baik strategi pemasaran Word of Mouth maka akan membuat semakin tinggi minat pelanggan untuk menjadi anggota (nasabah) pada Baitul Tamwil MuhammadiyahKota Bandar lampung. Selain itu berdasarkan hasil analisis SEM yang telah dilakukan diperoleh hasil untuk strategi pemasaran Word of Mouth juga sangat berpengaruh terhadap keputusan pelanggan untuk menjadi anggota (nasabah) pada Baitul Tamwil Muhammadiyah Kota Bandar Lampung. Dari hasil ini menunjukkan sesuai dengan pendapat Kotler (1997) bahwasannya strategi pemasaran Word of Mouth dinilai sangat efektif dalam memperlancar proses Marketing dan mampu memberikan keuntungan bagi perusahaan Kotler (1997). Strategi Word of Mouth mampu mempengaruhi minat dan keputusan pelanggan untuk menjadi anggota (nasabah) pada Baitul Tamwil Muhammadiyah Kota Bandar Lampung, dengan semakin bertambahnya anggota (nasabah) sehingga memberikan keuntungan bagi Baitul Tamwil Muhammadiyah.

\section{Jurnal Manajemen Indonesia}


Analisis SEM (Structural Equation Model) selanjutnya melihat pengaruh antara variabel produk pembiayan syari'ah terhadap minat dan keputusan menjadi anggota (nasabah) Baitul Tamwil Muhammadiyah Kota Bandar Lampung.

Hasil analisis menunjukkan bahwa produk pembiayaan syari'ah memberikan pengaruh yang signifikan terhadap minat untuk menjadi anggota (nasabah) pada Baitul Tamwil Muhammadiyah Kota Bandar Lampung, namun tidak memberikan pengaruh yang signifikan terhadap keputusan menjadi anggota (nasabah) pada Baitul Tamwil Muhammadiyah Kota Bandar Lampung. Selain itu minat pelanggan juga tidak memberikan pengaruh yang signifikan terhadap keputusan menjadi anggota (nasabah) pada Baitul Tamwil Muhammadiyah Kota Bandar Lampung.

Sebagai hasil penelitian dilihat dari pendekatan kualitatif dapat dikemukakan penjelasan dan pembahasan dari masing-masing variabel berdasarkan hasil wawancara.

\section{1) Word of mouth}

Word of Mouth dengan indikator membicarakan, mendorong dan merekomendasikan masih mempunyai pengaruh terhadap minat seseorang untuk mengambil keputusan untuk membeli atau mengambil suatu produk. Untuk lebih jelasnya pembahasan tentang tiap-tiap indikator Word of Mouth akan dijelaskan sebagai berikut:

\section{a) Membicarakan}

Strategi Word of Mouth melalui indikator membicarakan, menurut responden indikator ini terlaksana melalui kegiatan pengajian-pengajian, bakti social yang diadakan oleh Baitul Tamwil Muhammadiyah adapun yang dibicarakan tentang suatu prodak, kemudahannya, kemanfaatan atau kegunaannya, selain itu juga akan lebih mempermudah produk itu ditawarkan manakala dengan orang yang sudah pernah menjadi anggota.

\section{b) Mendorong}

Menurut responden adanya daya tarik terhadap Baitul Tamwil Muhammadiyah berhubungan dengan suatu keyakinan akan agama yang dianutnya. Selain itu juga Baitut Tamwil Muhammadiyah menggunakan prinsif syariah dalam pengelolaannya. Itulah pada akhirnya mereka tertarik untuk menjadi anggota atau nasabah Baitul Tamwil Muhammadiyah.

\section{c) Merekomendasikan}

Indikator ke tiga dari variable Word of Mouth dalah merekomendasikan. Menurut meraka menjadi nasabah Baitul Tamwil Muhammadiyah atas dasar kebutuhan dan menginginkan suatu perdagangan yang tidakl ada unsur ribanya. Berdasarkan hasil analisis terhadap jawaban responden ternyata pendekatan dengan cara persuasif, pemaparan tentang kelebihan, manfaat dan memberikan kepastian akan suatu produk, mengakibatkan para calon anggota merekomendasikan dirinya bergabung di dalamnya.

Ada beberapa hasil penelitian terdahulu yang mendukung terhadap hasil penelitian ini, salah satunya penelitian yang dilakukan oleh Mahendrayasa (2014), menyatakan bahwa Word of Mouth berpengaruh positif terhadap minat beli dan keputusan pembelian. Penelitian selanjutnya yang dilakukan oleh Syafaruddin (2016) menyatakan bahwa electronic Word of Mouth menjadi strategi pasar yang sangat penting dan berpengaruh terhadap pelanggan untuk memutuskan pembelian. Selanjutnya penelitian yang dilakukan oleh Nugraha dan Aditya (2015), yang menyatakan bahwa Word of Mouth berpengaruh signifikan terhadap keputusan pembelian dan keputusan pemebelian berpengaruh terhadap kepuasan konsumen. Penelitian yang berjudul Pengaruh Word of Mouth terhadap minat beli serta dampaknya pada keputusan pembelian, yang dilakukan oleh Rahma Nurvidiana dkk. Penelitian menyatakan bahwa Word of Mouth berpengaruh positif terhadap minat beli dan keputusan pembelian. 
Hasil beberapa penelitian tersebut, maka penulis dapat menyimpulkan bahwa Word of Mouth sebagai salah satu starategi pemasaran yang dapat digunakan untuk menyambungkan pesan, informasi dan produk melalui media lisan, tulisan maupun elektronik tentang sesuatu produk kepada konsumen. Semakin baik strategi marketing Word of Mouth dilakukan maka akan semakin menimbulkan minat dan keputusan untuk membeli atau menjadi bagian didalamnya.

\section{2) Produk}

Untuk penjelasan indikator produk, peneliti melakukan wawancara dengan pengelola atau manajemen Baitul Tamwil Muhammadiyah, yang ruang lingkupnya meliputi keadilan, kemitraan, transfaransi dan universal. Menurut hasil wawancara dengan pihak menajmen Baitul Tamwil Muhammadiyah, maka peneliti uraikan sebagai berikut:

a. Keadilan

Baitul Tamwil Muhammadiyah berusaha dalam menjalankan kegiatan simpan pinjamnya dengan menggunakan azas keadilan. Menurutnya azas keadilan wajib dibangun dalam setiap aktivitas perdagangan atau jual beli. Berangkat dari azas ini Baitul Tamwil Muhammadiyah mendapat kepercayaan dari masyarakat untuk terus menumbuhkan kegiatan ekonomi yang merata dan mampu mengurangi kemiskinan dan pengangguran.

b. Kemitraan

Menurutnya (manajemen) Kemitraan yang ditumbuhkan adalah kemitraan yang didasarkan atas keimanan. Dasar inilah yang melahirkan persahabatan, sepenanggungan saling membantu, memperkuat jaringan pengembangan usaha. Bentuk kemintraan yang banyak dilakukan antara Baitul Tamwil Muhammadiyah dengan para nasabah adalah prnsip bagi hasil terutama al-musyarakah dan Bai Al Murabahah.

c. Transparansi

Menurut management transparansi dimaksudkan adanya keterbukaan antara pihak management dengan para nasabah, baik terkait dengan program pengembangan usaha, keuntungan yang diperoleh mapun pengembangan sumber daya manusia melalui pelatihan dan workshop. Transparansi diimplementasikan melalui penerapan nilai-nilai kejujuran, kebenaran, akuntabilitas dan amanah.

d. Universal

Menurut hasil wawancara dengan pihak manajement Baitul Tamwil Muhammadiyah terkait dengan prinsif universal adalah Baitul Tamwil Muhammadiyah dalam menjalankan bisnis atau usahanya menganut prinsip Tauhidullah, berkeadilan, Ta'awun (saling tolong menolong), mengikuti sunnah dan contoh rasul.

\section{Kesimpulan dan Saran}

Hasil Penelitian diperoleh kesimpulan sebagai berikut:

a) Terdapat pengaruh yang positif Word of Mouth terhadap minat. Semakin tinggi Word of Mouth maka akan semakin tinggi juga minat nasabah. Secara signifikansi P Value nilainya 0,000 kurang dari 0,05 artinya ada pengaruh yang signifikan (berarti) Word of Mouth terhadap minat.

b) Terdapat pengaruh yang positif produk terhadap minat. Semakin tinggi produk maka akan semakin tinggi juga minat nasabah. Secara signifikansi P Value nilainya 0,039 kurang dari 0,05 artinya ada pengaruh yang signifikan (berarti) produk terhadap minat.

c) Terdapat pengaruh yang positif Word of Mouth terhadap keputusan. Semakin tinggi Word of Mouth maka akan semakin tinggi juga keputusan nasabah. Secara signifikansi P Value

\section{Jurnal Manajemen Indonesia}


nilainya 0,038 kurang dari 0,05 artinya ada pengaruh yang signifikan (berarti) Word of Mouth terhadap keputusan.

d) Terdapat pengaruh yang positif produk terhadap keputusan. Semakin tinggi produk maka akan semakin tinggi juga minat nasabah. Secara signifikansi P Value nilainya 0,579 lebih dari 0,05 artinya tidak ada pengaruh yang signifikan (berarti) produk terhadap minat.

e) Tidak terdapat pengaruh yang positif minat terhadap keputusan. Secara signifikansi P Value nilainya 0,954 lebih dari 0,05 artinya tidak ada pengaruh yang signifikan (berarti) minat terhadap keputusan.

Berdasarkan hasil penelitian yang sumbernya diperoleh dari pengolahan hasil analisis data, maka beberapa saran yang dapat diberikan kepada Baitul Tamwil Muhammadiyah adalah sebagai tindak lanjut ke depan dari hasil penelitian ini. Guna meningkatkan penghasilan suatu perusahaan maka strategi pemasaran Word of Mouth harus ditingkatkan agar daya tarik pelanggan untuk berminat dan memutuskan untuk memilih suatu produk atau bergabung menjadi anggota (nasabah) meningkat. Selain itu kualitas produk juga mempengaruhi minat pelanggan untuk memiliki atau bergabung menjadi anggota, sehingga perlu ditingkatkan produk sehingga minat pelanggan meningkat.

\section{Daftar Pustaka}

Abdad, M. Z. (2003). Lembaga perekonomian umat di dunia Islam. Angkasa.

Nugraha, A., \& Aditya, F. (2015). Pengaruh Word of Mouth terhadap Keputusan Pembelian dan Kepuasan Konsumen (Studi pada Konsumen Kober Mie Setan jalan Simpang Soekarno-Hatta nomor 1-2 Malang). Jurnal Administrasi Bisnis, 22(1).

Agustianto.

2011.

https://shariaeconomics.wordpress.com/2011/02/24/prinsipsyari\%e2\%80\%99ahdalam-ekonomi-dan-perbankan/, (10/05/2017)

Mahendrayasa, A. C. (2014). Pengaruh Word of Mouth Terhadap Minat Beli Serta Dampaknya Pada Keputusan Pembelian (Survei pada Mahasiswa Pengguna Kartu Selular GSM "IM3" Angkatan 2011/2012 dan 2012/2013 Fakultas Ilmu Administrasi Universitas Brawijaya Malang). Jurnal Administrasi Bisnis, 12(1).

Djamarah, S. B. (2008). Psikologi Belajar. Jakarta: Rineka Cipta.

Maru File, K., Cermak, D. S., \& Alan Prince, R. (1994). Word-of-mouth effects in professional services buyer behaviour. Service Industries Journal, 14(3), 301-314.

Hasan, A. (2010). Marketing dari mulut ke mulut. Word of Mouth Marketing, Media Pressindo, Yogyakarta.

Hasan, M. I. (2002). Pokok-Pokok Materi Teori Pengambilan Keputusan. Jakarta: Ghalia Indonesia.

Irawan, D.H. (2007). Jangan Salah Menilai Konsumen Indonesia. Majalah Marketing/Edisi Khusus/ II/2007.

Islahi, A. A., \& Thayib, A. (1997). Konsepsi Ekonomi Ibnu Taimiyah. Bina Ilmu.

Kotler, P. (1997). Manajemen Pemasaran: Marketing Management 9e Jilid 2.

Muhammad, BS. (2006). Bank Syariah Analisa Kekuatan, Peluang, Kelemahan, dan Ancaman. Yogyakarta: Ekonesia.

Nasution, S. (2004). Didaktik, Azas-Azas Mengajar. Bandung: Jemmars. 
Ng, S., David, M. E., \& Dagger, T. S. (2011). Generating positive word-of-mouth in the service experience. Managing Service Quality: An International Journal, 21(2), 133-151.

JURNAL

MANAJEMEN

INDONESIA

\section{Vol.17 No.3}

Desember 2017
Nurvidiana, R. (2015). Pengaruh Word of Mouth Terhadap Minat Beli Serta Dampaknya Pada Keputusan Pembelian. Jurnal Administrasi Bisnis Vol. 22 No. 2.

Prasetijo, R., \& Ihalauw, J. J. (2005). Perilaku konsumen. Yogyakarta: Andi.

Praswati, A. N. (2009). Analisis Faktor-Faktor Yang Mempengaruhi Komunikasi Word of Mouth Terhadap Minat Guna Jasa Ulang Studi Kasus Pada PT Nasmoco di Semarang. (Doctoral dissertation, program Pascasarjana Universitas Diponegoro).

Rangkuti, F. (2006). Measuring Customer Satisfaction Teknik Mengukur dan Strategi Meningkatkan Kepuasan Pelanggan Plus Analisis Kasus PLN-JP. Jakarta: Gramedia Pustaka Utama.

Slameto. (2010). Belajar \& Faktor-faktor yang Mempengaruhinya. Jakarta: Rineka Cipta.

Suganda, U. K. (2007). Islam \& Penegakan Ekonomi Yang Berkeadilan. Bandung: IRIS Press.

Sukardi. (2003). Bimbingan dan Penyuluhan Belajar di Sekolah. Bandung: Usaha Nasional.

Sumardy, M. S., \& Melone, M. (2011). The power of word of mouth marketing. PT. Gramedia Pustaka Utama. Jakarta.

Surya, M. (2004). Psikologi Pembelajaran dan Pengajaran. Bandung: Pustaka Bani Quraisy.

Syafaruddin, Z. (2016). Pengaruh Komunikasi Electronicword of mouth Terhadap Kepercayaan (Trust) dan Niat Beli (purchase Intention) serta Dampaknya Pada Keputusan Pembelian (Survey Pada Konsumen Online Shopping Zafertech. Com). Jurnal Bisnis dan Manajemen, 3(1). 